\title{
The industrial heritage around the coast of the Baltic sea at Pāvilosta municipality
}

\author{
Dace Ržepicka, Aija Ziemeḷniece, Una Īle, Latvia University of Agriculture
}

\begin{abstract}
Today, in the coastal area of the municipality of Pāvilosta, preservable natural riches meet - the seashore bluff of the Baltic Sea, the nature reserves "Ziemupe", "Gray Dune", the old and still living craft of the fishery of the inhabitants of the coastal region. The values of the industrial heritage of the end of the $19^{\text {th }}$ century are readable - the jetties, Pāvilosta, the lighthouse of Akmeṇrags, chimneys of kilns, farm buildings at Upesmuiža, which presently create the opportunities for prospective management and development of the society. The historical experience and the technological requirements of the management of the $21^{\text {st }}$ century affect the existing cultural landscape and motivate the perspective of development.

This is attributable to tourism and the trend of searches for the living space in the municipality of Pāvilosta, proving that this location has the uniqueness of the ecological core and identity of the location. The fishery sector at Pāvilosta is strengthened by the newly built fishing quay and the modern marinas on the right and the left bank of the river Saka, reconstruction works of the jetties and the lighthouses. In renovating the existing building or constructing new buildings, there is an expressed tendency to maintain the scale of the building volume, coloring, and texture of building materials that promote the historic and the new spatial harmony. The lighthouse of Akmeņrags, which creates a pronounced dominant in the landscape, has become a favorite tourist destination.

Keywords: cultural and historical landscape, industrial heritage, building scale, coloring, texture
\end{abstract}

\section{Introduction}

Through researching the landscape space of the industrial heritage in the municipality of Pāvilosta along the coastline of the Baltic Sea, the five kilometers wide coastline is surveyed, according to the Protection Zone Law [8] and the available histories and archive data are compared with the existing natural situation on the site typology and the current situation. In the municipality of Pāvilosta, the industrial heritage of the coastal zone consists of factories and household structures of the former manor estates, as well as fishery and shipping facilities, lighthouses, road building, and bridges. The industrial heritage also includes the narrowgauge railway and the station built at the start of the $20^{\text {th }}$ century. The most significant industrial heritage focuses at Pāvilosta with the port founded in 1879. The boom began with the construction of Liepāja Karaosta and the opportunity to transport thither both stones and agricultural production. At the start of the 1920s, fishery, shipping, shipbuilding, and trading have already been developed at Pāvilosta.

The most remarkable sites of the industrial heritage in the municipality of Pāvilosta have survived since the start of the $70 \mathrm{~s}-80 \mathrm{~s}$ of the $19^{\text {th }}$ century and the start of the $20^{\text {th }}$ century. After the war in the $50 \mathrm{~s}-80 \mathrm{~s}$ of the $20^{\text {th }}$ century, the life of the coastal people was rapidly changing, the number of the population was reduced by war and deportations which was facilitated by the presence of the army and the coastal isolation. The individual fishing collapsed, fishery gear and attributes disappeared, such as stakes, plank-ways, and trestles, railway installations were eliminated [9]. The manor outbuildings have disappeared,

the remaining ones are often exposed to a rough rebuilding without architectural understanding. In turn, at the estuary of the river Saka at Pāvilosta the port reconstruction works are in progress and there is a boom in the sector of tourism and fishery. It is important not only to transform and regenerate but also to maintain the material evidence of the town's economic and cultural growth in the form of industrial sites. The provision of this goal will depend not only on the economic development in the early $21^{\text {st }}$ century but also from the political and economic power and the desire to recognize and appreciate the most significant historical stages of urban growth [11].

Not only the coastal economic and historical circulation and building but also the ecological core form a very strong context for the perception of the identity of the site. It is created by silhouettes and compositional elements which are made up of landscape horizontals and verticals on the coast masts of ships and yachts, lighthouses, windmills. The unique sight points from the seashore bluff and the manor houses ranked there, as well as the oldest parts of Pāvilosta, are an unrivaled treasure of the municipality and the heritage to be protected. The rapid disappearance of the small train mazbānītis, the ancient fishery, drying of nets and fish smoking have disappeared from the landscape and only the intangible cultural heritage has survived.

The aim of the research is to assess the context of the landscape space and the industrial heritage of the municipality of Pāvilosta lying on the coastal area of the Baltic Sea. A number of assignments have been moved forward for the research, namely, to: 
- Identify the diversity of the industrial heritage sites in the area under the study;

- Assess the landscape space of the industrial heritage of Pāvilosta in two sections of the coastal area - research of the scale of the industrial sites and the differences in the building density;

- The spatial aspects of the green structure;

- The coastal brownfield sites and causes.

\section{Materials and Methods}

The industrial site as a spatial nucleus of the economic activity affects the form creation of the landscape. The different types of economic functions have determined the historical locations of transport and pedestrian streams. The industrial environment expresses the spatial identity and increases recognition of certain places. The industrial landscapes of the coastal area of the Baltic Sea from Kolka to Pape are found both in the urban environment and in the landscape of the countryside. The heritage of the industrial environment is readable both through the material and the intangible heritage. Many sites and landscape spaces around them have disappeared and the evidence can only be found in archival documents.

The concept of the industrial heritage as a concept of the cultural and the historical heritage is reflected in the regulations adopted by the Cabinet of Ministers. "The field of cultural heritage in the European practice covers the protection of immovable and movable cultural monuments and the identification, research, recording, preservation, use, and involvement of the cultural and historical heritage in the circulation of modern life. The cultural heritage of this program consists of:

- The architectural heritage;

- The archaeological heritage;

- The monumental, sacred, and applied art heritage;

- The industrial heritage;

- The underwater heritage [7]

- The Latvian Industrial Heritage Fund (LIH Fund) has developed the following typology of the industrial heritage:

- Production plants - factories, kilns, breweries, dryers, warehouses, workers' dwelling houses, separate production-related items (machine tools, equipment, boats, etc.), etc.;

- Bridges - street and rail bridges, viaducts, ferries, etc.;

- Railway installations - railway lines, stations, etc.;

- Lighthouses, pilot houses, and towers;

- Hydrotechnical structures - jetties, dams, canals, etc.;

- Road construction and signs - road sections, postal stations, etc.;
- Urban objects - fire stations, postal buildings;

- Water supply objects - wells, water towers, water pumps, water supply pumping stations, etc.;

- Electrical installations;

- Mills - watermills, windmills;

- Military installations - fortresses, fortifications, cannons, etc..

- The areas in which the sites of the cultural heritage are available have significant benefits for attracting tourists. The economic benefits of the tourism infrastructure - jobs, markets for goods and services, and the resulting taxes in the State and local government budgets depend on a number of factors - not only on the cultural heritage. The existence or absence of the cultural heritage determines the tourism potential of the area concerned. As the cultural sector is an important employer, there is a clear link between culture and the economic policy at the regional, national, and the European level [10].

In the research, the importance of the waterfront adjacent to the industrial heritage sites along the Baltic Sea coast is studied, including river estuaries and river sections. These are locations that historically provided transport links with production sites but nowadays the landscape environment is their value. The old production areas have the potential for the creation of industrial parks and the boom of tourism. The areas under development and the sites should consider the protected areas along the remarkable natural sites of the municipality of Pāvilosta - the seashore bluff of the Baltic Sea, which has recently been subject to severe erosions, Pāvilosta "Gray Dune", the Nature Reserve "Ziemupe".

While studying the landscape space of the industrial heritage in the coastal area of the Baltic Sea within the municipality of Pāvilosta, its 2 sectors have been surveyed:

1) The area research sector $A$.

The former manor areas of the parish of Saka - Labrags Manor, Ulmale Manor, Strante Manor, the seashore bluff Ulmale-Strante, and Akmenrags.

2) The area research sector $B$.

The town of Pavilosta and the historic factories at Upesmuiža near the steep bank of the river Saka.

Several methods have been used for the research:

- The comparative analysis - the study of the dynamics of development of the area, based on the analysis of historical materials and the comparison of the current situation, as well as the analysis of processes in certain periods;

- The complex method, by synthesizing the scenic, cultural environment, economic, architectural and spatial aspects; 
- The landscape identity model, the method of the visual, historical, cognitive element recognition;

- The study of literature, spatial development plans, archival materials.

\section{Results and Discussion}

The survey of the area research sector $\mathbf{A}$ shows that the boundaries of the historical areas of the former manors have not survived, as the land of the manors was distributed already in the 1990s to the new owners who have created a new landscape space during the past hundred years. Some of the areas of the former manors have been overgrown by trees or a landscape space of a new scale has been created, and, therefore, it is visually difficult to perceive the historical landscape as a compositionally uniform one. The old building of the manor has been preserved in part. The outbuildings and the production buildings have changed their function several times, they can be rebuilt or incorporated into a new building, thus losing the original scale.

Through researching the archival materials, the transformation of the coastal landscape space is well readable. This also applies to the vertical accent that has disappeared from Labrags Mansion - the chimneys of the brick kiln on the seashore bluff at the mouth of the river Riva. In recent years, the seashore bluff has undergone considerable erosions, exposing clay layers and promoting their slipping into the sea. As an industrial heritage site, the recently renovated wooden bridge across the river is the only wooden stanchion bridge in Latvia. In turn, the wool carding of Labrags Manor has disappeared, but the manor mill has survived.

The houses of Ulmale Manor were destroyed during World War I by the firing of the ships. The outbuilding, a long single-storied boulder building, located on the edge of the Ventspils - Liepāja highway, have survived. Only the oak alley ingrown in a meadow which extends from the highway to the side of the sea evidences that once Strante Manor was located there. In this section of the seashore bluff, the cultural and historical landscape consists of maritime meadows and shimmering waves on the horizon.

In the coastal research section, the most important site of the industrial heritage is the red brick lighthouse of Akmeñrags and its complex of houses at the seashore. The seashore bluff of Ulmale - Strante is the highest one in Latvia and reaches even $22 \mathrm{~m}$ in height, though exposed to the effects of nature, it is often affected by erosion. The beach at this location is very narrow. At the top, the landscapes of the flat meadows allow you to watch the sea and the wide surroundings through plains interpenetrating with the sea.

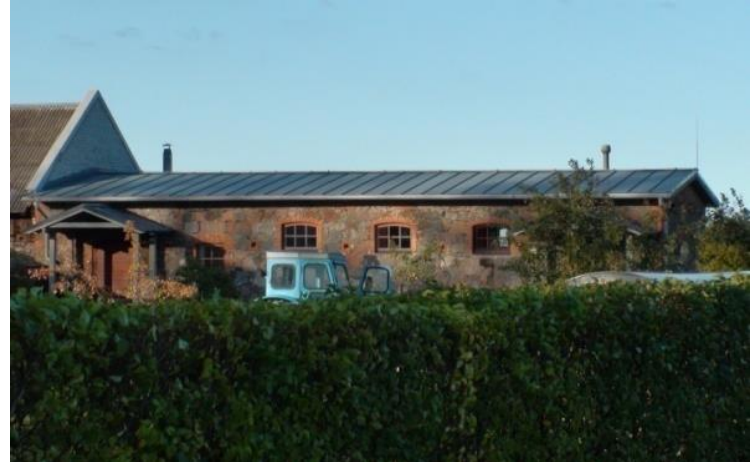

Fig. 1. The granary of Ulmale Manor [photo by the authors, 2017]

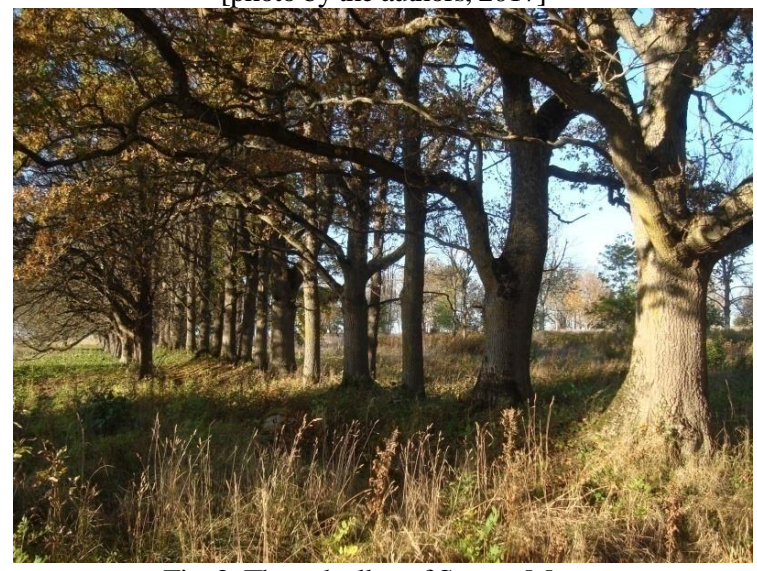

Fig. 2. The oak alley of Strante Manor [photo by the authors, 2017]

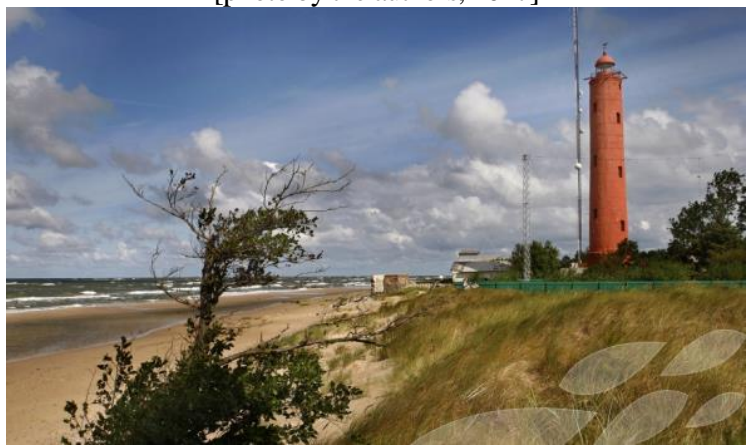

Fig. 3. The lighthouse of Akmenrags

[https://www.google.lv/search?q=

https://www.google.lv/search?q=labrags\&client=firefox-b$\mathrm{ab} \& \mathrm{dcr}=0 \& \mathrm{tbm}=$ isch\&sou]

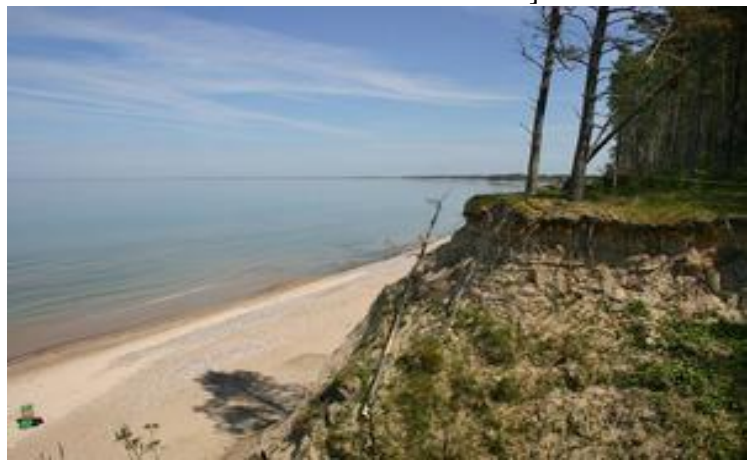

Fig.4 .The seashore bluff of Labrags [https://www.google.lv/search?q=

https://www.google.lv/search?q=labrags\&client=firefox-b$a b \& d c r=0 \&$ tbm $=$ isch\&sou] 


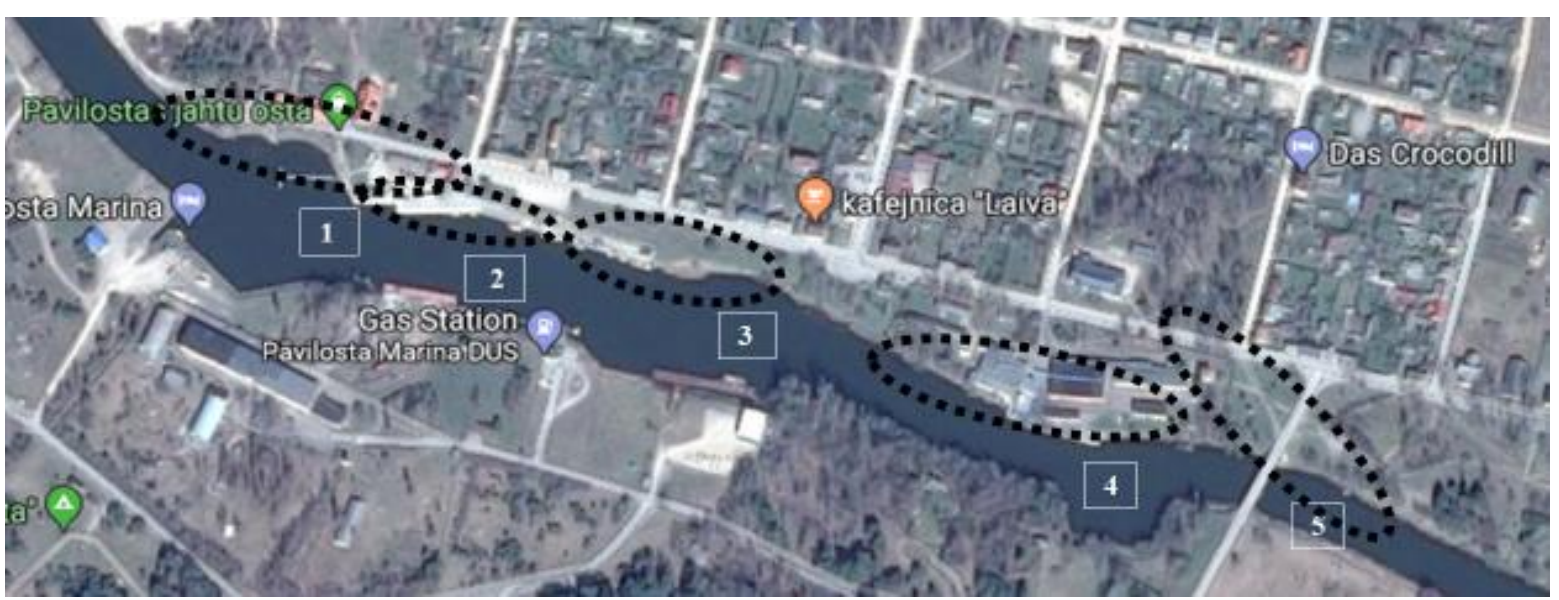

Fig. 5. The study of the landscape spaces of the right bank of the river Saka [created by authors]

Research of the coastal area in the sector B considers the sites of the industrial heritage at Pāvilosta and $3 \mathrm{~km}$ away - in the area of the former manor at Upesciems (Sackenhausen).

As it is already said, during the period from the 1970s until nowadays, the coastal area around Pāvilosta has experienced a number of booms phases. The other strong point of development of Pāvilosta was the adjacent Upesmuiža and its agricultural output, the sale of bricks and alcohol, which provided a rapid development of Pāvilosta and the manor estate. It was also contributed by the fact that the development of both Pāvilosta and the manor estate was encouraged by two enterprising brothers Paul and Otto von Lilienfeld.

Pāvilosta as a shipyard site and the provider of trade routes, in the prewar years, began to build the infrastructure of a small residential area with a street network of the village. Unfortunately, the two world wars and the Soviet occupation of the $20^{\text {th }}$ century have destroyed both the cultural and historical heritage and the importance of the port. Only the last 20 years have brought tourism attraction and the protection of the ecological core for maintaining and understanding the identity of the site.

At Pāvilosta, the river Saka as the "blue spine" and its green banks build not only an economically important artery but also determine the expressiveness and picturesqueness of Pāvilosta. It may be well readable from Dzintaru street which leads the newcomer into the city along the river bank to the sea. The parallelism of the street side-by-side to the bank of the river Saka, approximately $1 \mathrm{~km}$ in length gives the town a sense of the sea coming into the historical part of the building. The parallelism of Dzintaru street creates several landscape spaces for the right bank of the river Saka.

The jetty area, dominated by the context of the sea, the jetty, and the beach:

1. The flat bank line of the river and the perception of the historic building area (60 $\mathrm{m}$ in length);
2. The fishing quay area with a narrow floodplain meadow lane (the former marina where fishermen had built a fishing net hut) alongside the low-rise building on Dzintaru street $(150 \mathrm{~m})$;

3. A dense cover with an enclosed production area, blocking the sight lines to the banks of the river Saka in two separate segments $(60 \mathrm{~m})$;

4. The park area along the river up to the building of the 1970s (200 m);

5. The zone context with the forest landscape of the left bank of the river Saka.

Each of the above zones brings a different compositional character to the town. The first 3 areas that lay close to the sea are the most colorful and different in scale, building density, and architectonic stylistics. In studying the area in detail, the level of the visual and aesthetic quality of each one is described. The sight lines from Dzintaru street to the river Saka (from Vilınu to Tirgus street $150 \mathrm{~m}$ ) are the most expressive as they are open and not hidden by buildings or woody plant species. This is the historic berth on the banks of the river Saka with stakes, net trestles, net huts, boat plank-ways gone - nowadays it is a flat, green meadow.

In this area, the sight lines are long, and their deep plan features a readable forest landscape of the opposite bank of the river, complemented by a romantic mood with a marina. In turn, the right bank of $150 \mathrm{~m}$ in length serves for a fishing boat quay, so forming an impressive silhouette. The mentioned mooring lane on both sides of the river is visually changing with the seasons. A load of summer tourism turns the banks of the river into a dense marina. In the silhouette, the yacht masts attenuate the building of neighboring warehouse buildings on the left bank of the river. In turn, in the other seasons, with the decline of tourism, the industrial atmosphere prevails in the silhouette.

From Viḷnu street to Vitolu street, the sight points on the river $(80 \mathrm{~m})$ are completely hidden by warehouses and shrub rows which are opposite to the openness of the river previously examined. 


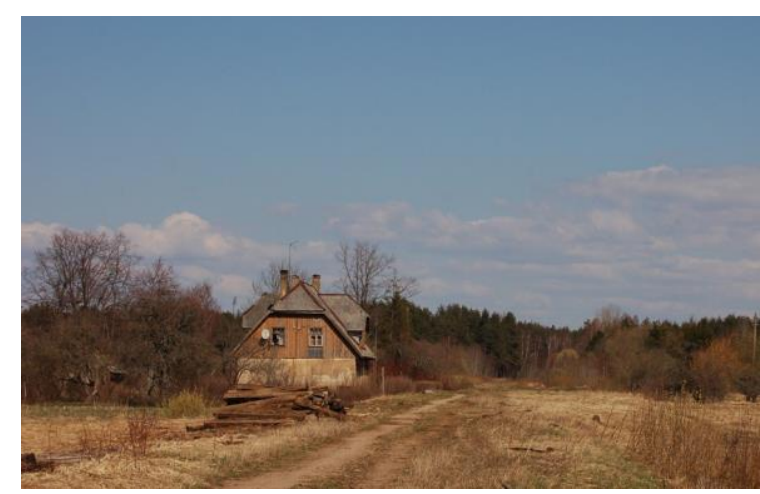

Fig. 6. Kursa Station and the dismantled rail path [http://www.parovoz.com/newgallery/?ID $=316943 \&$ LNG=RU\#picture $]$

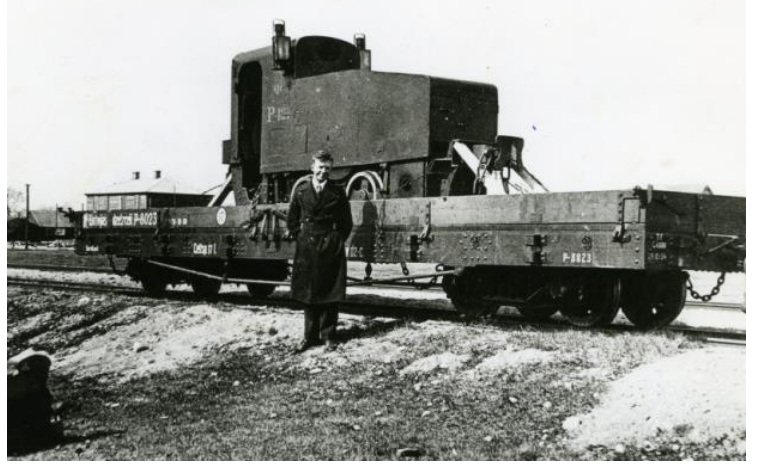

Fig. 7. Old rails at Pavilosta [9]

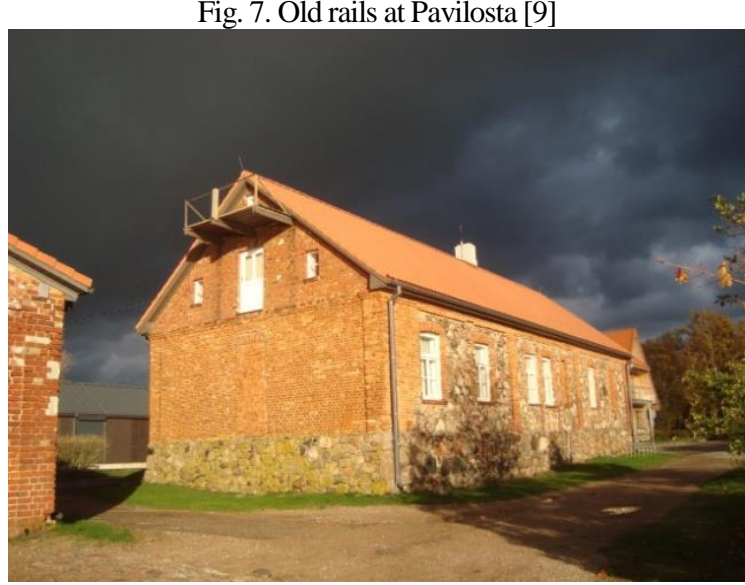

Fig. 8. The former pilot house [photo by the authors, 2017]

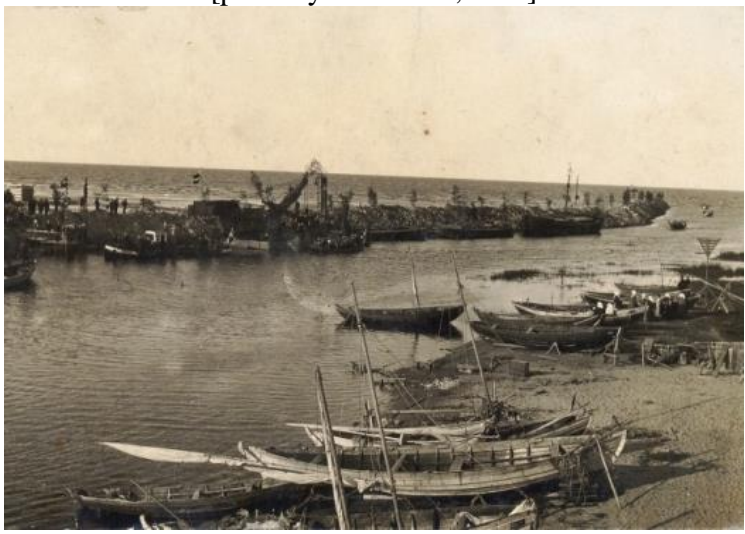

Fig. 9. The quay zone of the left bank of the river Saka in the 1920s [9]
The continuous housing creates a markedly industrial end of Dzintaru street near the former pilot house where the dune zone and the exit to the sea jetty begin. Opposite the dunes, on the left bank of the river in the 1970s, an exaggerated production building has been constructed in the proportion that drowns the expression of the bank. The arrival of vessels to the river Saka is provided by the old stone-stacking jetties with two lighthouses, where their reconstruction works have begun.

Similarly, there are a number of sight lines between Tirgus street and Kalna street in a $150 \mathrm{~m}$ long area enclosed with hedges and overgrown shrub groups. This is where the steep bank of the river begins, the expressiveness of which is not even noticeable. In this street section, alongside the shore, there is a construction area of the production site, which is surrounded by a high fence, which, together with the trees, forms an exaggerated scale and disrupts the compositional integrity of Dzintaru street.

Along with Kalna street, the two parkland areas begin, which locating on both sides of Dzintaru street, form a peculiar green gate before entering the historical center of the town. When comparing the archive's photo-capture, it's evident that a hundred years ago Baznīckalns has been a dune without trees around. Currently, the dune is covered by a large number of trees, forming separate groups of glades.

The southern side of Dzintaru street connects to the bank of the river, while the northern edge is connected with the small streets of Old Pavilosta with its mansions and the gardens, which end in the Gray Dune. It is a compositional peculiarity of the building of Pavilosta where the urban space is enclosed in the elements of the ecological core between the Gray Dune Lane and the bank of the river Saka. In turn, the "canvas network" of the streets contains both ecological cores together. The narrow-gauge train that was connected to the Ventspils-Liepaja and Alsunga line has contributed to a very strong growth of Pāvilosta. Transportation of the domestic agricultural products, lumber, boulders, brick to ports accounted for a good contribution to the coastal economic development. The economic prosperity was destroyed by the two world wars and the period of the Soviet occupation. The consequences of that led to the dismantling of the train paths in the 1990s. The same applies to the entry of barges at Pāvilosta. The archive photo materials brightly reflect the area of the giant glade near Dzintaru street until the war. Currently, the site of the former glade is occupied by a meadow and a cover of woody plant species. By the disappearance of the rail and the load of the maritime transport, Pāvilosta as a powerful production point with an ice-free port is gone. 


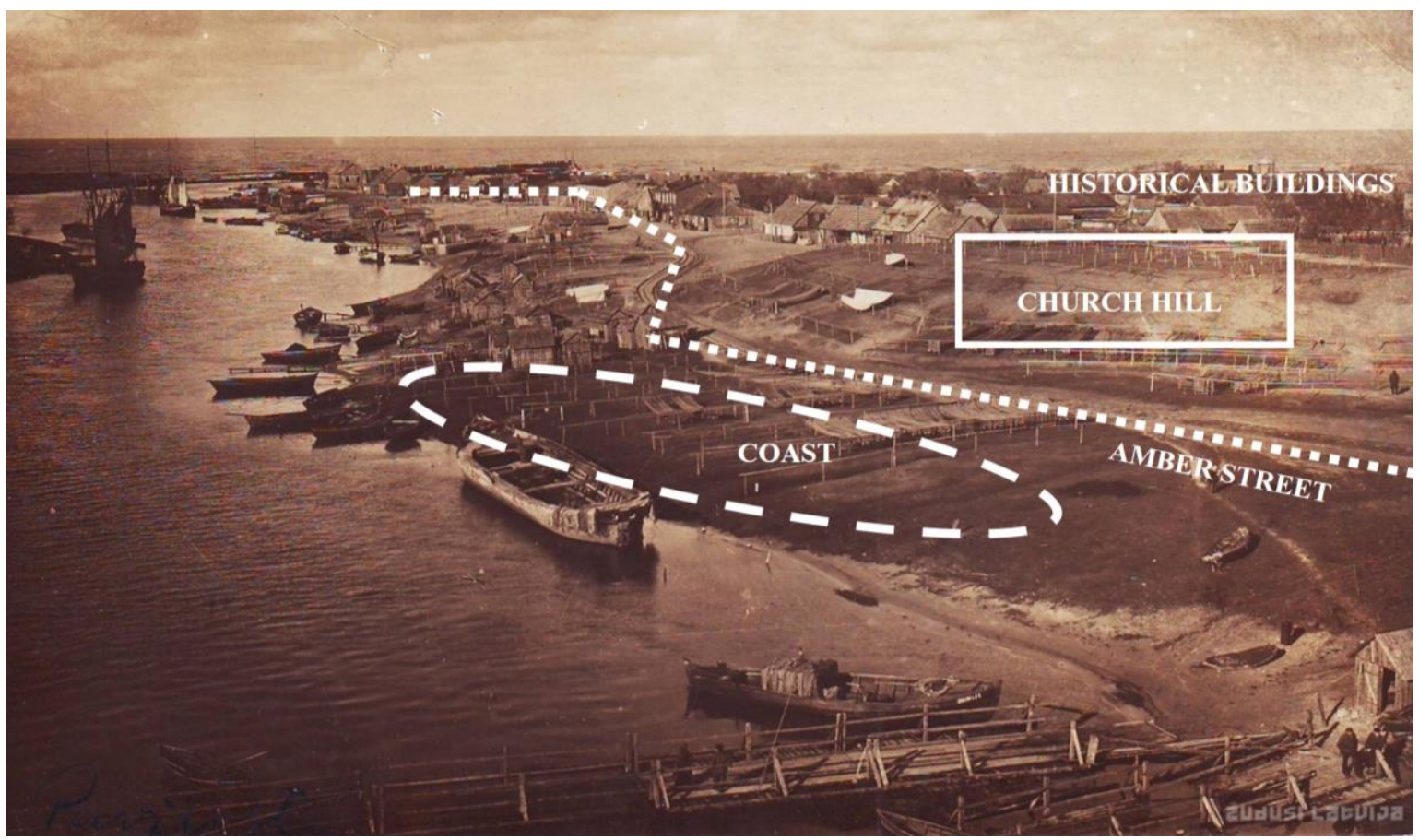

Fig. 10. The right bank of the river Saka with a glade near Dzintaru street, Baznīckalns, and the fishermen village, 1920 [created by the authors; 6]

Upstream the river Saka, in the distance of manor building on the eastern side, the old windmill approximately $2 \mathrm{~km}$ from Pāvilosta - the industrial heritage of the marine landscape is continued by Upesmuiža (Sackenhausen - the property of Baron von Zaken). Its development dates back to the turn of the $19^{\text {th }}$ and $20^{\text {th }}$ century, locating near the former Apriku road beside the flow of the Minde brook into the river Saka. The industrial production of the manor estate was provided by several strong aspects of the ecological core and the infrastructure:

1) The dirt road to Liepāja.

2) The rail from Alsunga to Liepāja.

3) The navigable river Saka with a passage to the sea;

4) Land fertility (fields, meadows);

5) Clay deposits.

The above values of the ecological core provided the construction of several production buildings - the windmill, brick kiln, and distillery. For the storage of the finished products, a granary, barn, cellar were built. Opposite the kiln over the river Saka, there was a raft bridge. Clay mine beds around the brick kiln are also visible today, creating separate pools. Considering the economic situation, a hundred years ago, the production volume of the manor was incredibly high. The field and meadow areas on both banks of the river Saka (see the old map) give evidence of the fertility of the soil. In the today's situation, part of the manor building, the so-called manor house (1905) is gone. The historic distillery and brick kiln building, built in the red brick architectural stylistics of the late $19^{\text {th }}$ century have survived. The old servants' house of the manor is also inhabited. In turn, away from the center of the has survived [12]. At Upesmuiža, the confluence of the river Tebra and the river Durbe, as well as the flow of the Mindes brook represented a very important support point for the agricultural development. Upstream the river Saka, a railway bridge over the river Saka has survived.

Today, both the historic dirt road from the manor to Apriki and the rail path to Alsunga are gone. Clay mines like giant pools, which stood at roadsides, are now noticeable in the middle of the fields, since in the postwar years under the effects of drainage agricultural areas developed. After the agrarian land reform in the 1920s, the land of the manor estate was split to build new farms with apple orchards instead of manor fields and meadow areas. The dairy built in the 1930s at the roadside from the estate to Apriki has also disappeared.

The modern rural industrial farming has disrupted the scale of the historic rural mosaic-like landscape.

The river Saka has served as a trade route to the exit to the sea. Historically, it has been referred to in the descriptions as the Saka port, which was located around $5 \mathrm{~km}$ up from Pāvilosta. The name of Saka was first mentioned in 1230. From the second half of the $13^{\text {th }}$ century up to the Livonian war, Saka is a property of the bishops, who have repeatedly feuded it. In the $15^{\text {th }}-18^{\text {th }}$ century, Saka is managed by the Osten-Sacken family. At the start of the river Saka (the point of confluence of the river Tebra and the river Durbe), there was the center of Saka (Saceze) with the Kursu and Bruninieku mounds, 


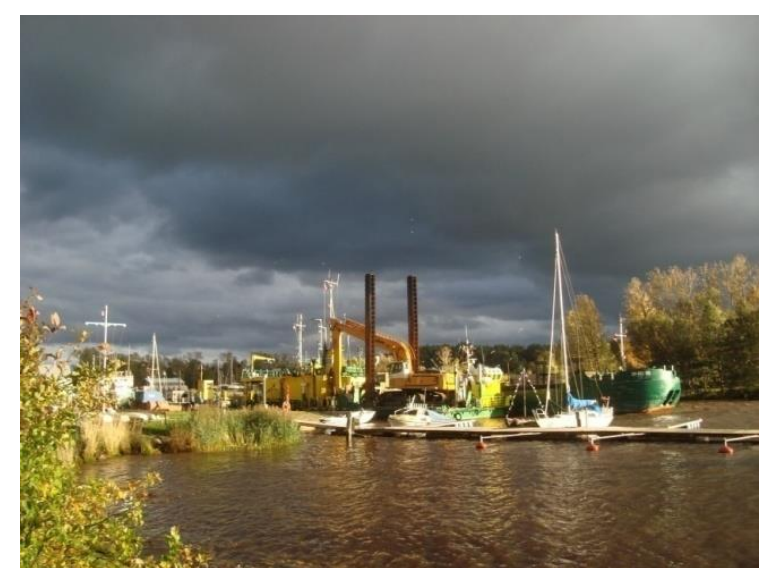

Fig. 11. A modern port with a marina [photo by A. Ziemelniece, 2017]

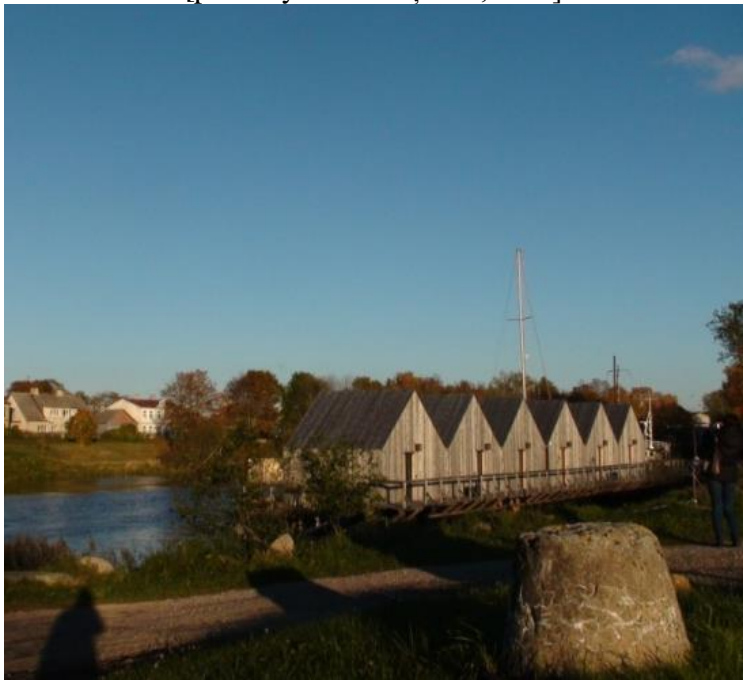

Fig. 12. Tourist accommodations, with boat planks [photo by A. Ziemelniece, 2017]

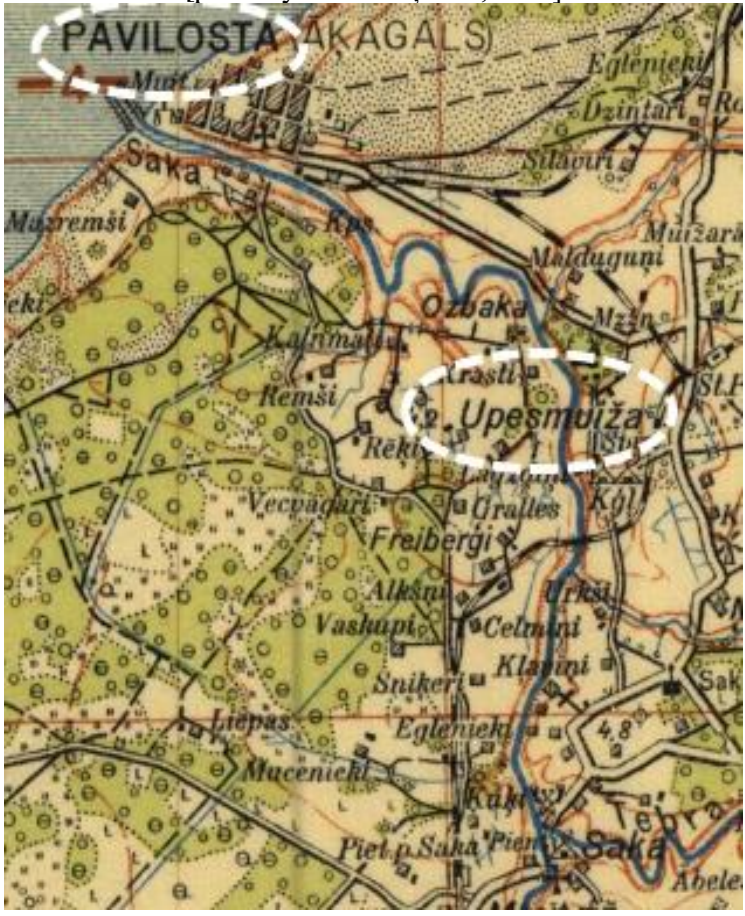

Fig. 13. Pāvilosta and Upesmuiža (Sackenhausen) railway network linking [created by authors; 6]

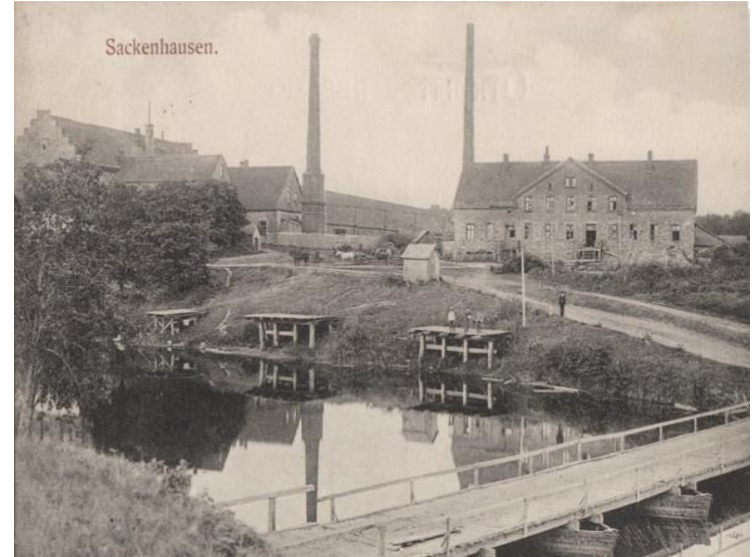

Fig. 14. Chimneys of the brick kiln and the distillery of Upesmuiža [http://www.zudusilatvija.lv/objects/object/3614/] with the Leja Evangelic Lutheran Church of Saka. During the reign of Duke Jacob (1642-1682), in their interests, the port of Saka was used by merchants of Aizpute. Within a year, the port was entered by $50-150$ merchant vessels, mostly from Holland. The busy port life was interrupted by the Swedish-Polish war. Until today, one of the port warehouses has survived [9].

\section{Conclusion}

The transformation of the industrial heritage of the municipality of Pāvilosta has been affected by a number of historical periods. The beginnings of the development of the locality were contributed by the nearness of Liepāja and the construction of a naval port in the second half of the $19^{\text {th }}$ century. The development of the coastal industrial environment started to emerge in the second half of the $19^{\text {th }}$ century and the emergence of the town of Pāvilosta and its boom, devastating wars in the $20^{\text {th }}$ century (1914-1918, 1940-1945), the time of the free state (1918-1940), the Soviet occupation and collectivization time (1945-1990), the impact of the public attitude, awareness, and legislation of the renewed Latvia on the development of the cultural and historical heritage. Each of the periods heralds the political and economic current, the change of the structure, compositional design or functional significance in the landscape spaces of the industrial heritage.

The awareness and the study of the industrial heritage sites promote the understanding of the stages of development of the society, the development of technologies and the economic activity at the local and a broader context, craft skills, contributions of the industrialization in the national economy.

This is attributable to the recovery process of the identity of Pāvilosta - bringing in a new low-rise residential building that keeps the height, roof slopes, coloring, the architectural and compositional structure of the historic building. 
In turn, the historic manor locations after listing of the land and real estate, are necessary to be attracted to conservation, preserving the brickwork of the old building without losing the scale and nature of the building. In characterizing the areas of the industrial heritage, the diversity of the sites and landscape spaces is observed:

- After the study of the historical documentation, the density of the landscape space of the industrial heritage has become thinner which changes the scale of the historic space;

- The green structures play a major role in the expressiveness of the coastal landscape spaces;
- Waterfronts in most sites have lost their historical significance;

- The sites of the industrial heritage often mark significant verticals in the cultural landscape, determining the identity of the site (the chimneys of the kiln of Upesmuiža, the lighthouse of Akmenrags, the location of the former berth at Pāvilosta. etc.);

- The degraded historical areas occupy a considerable part of the landscape space;

- The development of the industrial heritage is hampered by the today's low economic situation, tax policy, development planning opportunities, population fluctuations in municipalities.

\section{References}

1. Ainavu aizsardzība. VARAM, 2000, 91 lpp.

2. Altbergs T., Augustāne K., Pētersone I. Dzelzceḷi Latvijā. Rīga: Jumava, 2009, 169. lpp.

3. Bells S., Nikodemus O. Rokasgrāmata meža ainavas plānošanai un dizainam. Rīga: Valsts meža dienests, LTS International Ltd., 2000. 75 lpp.

4. Briṇkis J., Buka O. Regionālā attīistība un prognostika pilsētplānošanas kontekstā. Rīga: RTU, 2008, 191 lpp.

5. Briṇkisis J., Buka O. Zemes ìpašumu vērtēšana un taksācija pilsētplānošanā. Rīga: RTU, 2008. 50 lpp.

6. Latvijas karte - 1937.

7. Ministru Kabineta pieņemtais sēdes protokols Nr. 7 "Par Nacionālo programmu "Kultūra". 08.02.2000.

8. Ministru kabinets. Aizsargjoslu likums. 20.06.2016.

9. Pāvilostas muzeja materiāli. 2017.

10. Pūḳis M. Kultūras mantojuma sociālā un ekonomiskāa loma. Rīga: LU, 2011 [tiešsaite 12.11.2017] http://mantojums.lv/media/uploads/dokumenti/petijumi/pukis_kulturas_mantojums_ekosoc_loma.pdf

11. Ržepicka D., Ziemeḷniece A. Context of trade canal and industrial heritage in Liepaja. Rezekne Academy of Technologies. 11th International Scientific and Practical Conference, 2017. [tiešsaite 12.11.2017] http://conferences.ru.lv/index.php/ETR/ETR2017/index

12. Teivens A. Latvijas dzirnavas = Mills in Latvia = Die Mühlen in Lettland. Stokholma: Daugava, 1985. 297 lpp.

\section{INFORMATION ABOUT AUTHORS:}

Dace Ržepicka, Mg. arch., doctoral student at Faculty of Environment and Civil Engineering, Department of Landscape Architecture and Planning of the Latvia University of Agriculture, 22 Liela iela, Jelgava, Latvia, LV-3001. E-mail: dace.rzepicka@inbox.lv

Aija Ziemeḷniece, Dr.arch., Professor at Faculty of Environment and Civil Engineering, Department of Landscape Architecture and Planning of the Latvia University of Agriculture, 22 Liela iela, Jelgava, Latvia, LV-3001. E-mail: aija@k-projekts.lv

Una Īle, Dr. arch., Assist. Prof. (since 2012) at Faculty of Environment and Civil Engineering, Department of Landscape Architecture and Planning of the Latvia University of Agriculture, 22 Liela iela, Jelgava, Latvia, LV-3001. E-mail: una.ile@1lu.lv

Kopsavilkums. Pētot Pāvilostas novada industriālā mantojuma ainavtelpu Baltijas jūras piekrastēe, ir apsekota piecu kilometru plata piekrastes josla, atbilstoši Aizsargjoslu likumam [1] un salīdzināti pieejamie vēstures un arhīvu dati ar esošo situāciju dabā par objektu tipoloǵiju, skaitu un aktuālo stāvokli. Pāvilostas novadā piekrastes joslā industriālo mantojumu veido ražotnes un saimnieciskās būves bijušo muižu īpašumos, kā arī zvejniecības un kuǵniecības objekti, bākas, ceḷu būves un tilti. Industriālajam mantojumam pieder arī 20. gs. sākumā izbūvētais šaursliežu dzelzceḷš un stacijas. Nozīmīgākais industriālais mantojums koncentrējas Pāvilostā, kuras osta dibināta 1879. gadā. Tās uzplaukums aizsākās līdz ar Liepājas karaostas izbūvi un iespēju transportēt turp gan akmeṇus, gan lauksaimniecības produkciju. 20. gs. sākumā Pāvilostā jau bija attīstījusies zvejniecība, kuǵniecība, kuğu būve un tirdzniecība.

Ievērojamākie industriālā mantojuma objekti Pāvilostas novadā ir saglabājušies no 19. gs. 70.-80.gadiem un 20. gs. sākuma. Pēc Otrā pasaules kara 20. gs 50.-80. gados piekrastes laužu dzīve strauji mainījās, iedzīvotāju skaits kara un deportāciju rezultātā samazinājās, ko sekmēja armijas klātbūtne un piekrastes izolētība. Izsīka individuālā zvejniecība, izzuda zvejniecības rīki un atribūti, kā vabas, krāg̣i un steḳi, likvidēti dzelzceḷa objekti.

Zudušas muižu saimniecības ēkas, atlikušās bieži pakḷautas nesaudzīgai, bez arhitektoniskas izpratnes, pārbūvei. Turpretim, Pāvilostā Sakas grīvā norit ostas atjaunošanas darbi un vērojams tūrisma nozares un zvejniecības uzplaukums. Ir svarīgi ne tikai pārbūvēt un reǵenerēt, bet saglabāt materiālas liecības par 
ekonomisko un kultūras izaugsmi industriālo objektu formā. Šī mērķa nodrošinājums būs atkarīgs ne tikai no ekonomiskās attīstības 21.gs. sākumā, bet arī no politiskās un ekonomiskās varas spējas un vēlēšanās atzīt un novērtēt pilsētas izaugsmes nozīmīgākos vēsturiskos posmus".

$\mathrm{Ne}$ vien piekrastes saimnieciski vēsturiskā aprite un apbūve, bet arī dabas pamatne veido lıti spēcīgu kontekstu vietas identitātes uztverei. To rada silueti un kompozicionālie elementi, ko piekrastē veido ainavtelpas horizontāles un vertikāles - kuğu un jahtu masti, bākas, vējdzirnavas. Unikālie skatupunkti no jūras stāvkrasta un tajā sarindotām muižu ēkām, kā arī Pāvilostas vecākās daḷas, ir novada neatkārtojamā bagātība un saudzējamais mantojums. Strauji izzudušais mazbānītis, senā zvejniecība, tīklu žāvēšanas un zivju kūpināšanas darbības liecinieki ir zuduši ainavā un saglabājies vairs tikai kā nemateriālais kultūras mantojums.

Industriālais objekts kā saimnieciskās darbības telpiskais kodols ietekmē ainavas formveidi. Dažādi saimniecisko funkciju veidi ir noteikuši vēsturiskā transporta vietas un gājēju plūsmas. Industriālā vide izsaka telpisko identitāti un veicina noteiktu vietu atpazīstamību. Baltijas jūras piekrastes kultūrainavā no Kolkas līdz Papei industriālās ainavtelpas ir sastopamas gan pilsētvidē, gan lauku ainavā. Mantojuma liecības industriālai videi ir nolasāmas gan materiālā, gan nemateriālā mantojuma veidā. Daudzi objekti un ainavtelpas ap tiem ir zudušas, un liecības ir atrodamas vien arhīvu dokumentos.

Pētījumā izzināta industriālā mantojuma objektiem piegulošo ūdensmalu nozīme Baltijas jūras piekrastē, ietverot upju grīvas un upju posmus. Tās ir vietas, kas vēsturiski nodrošināja transporta sasaisti ar ražošanas objektiem, bet mūsdienās to vērtība ir ainaviskā vide. Vecās ražošanas teritorijas ir potenciāls industriālo parku izveidei un tūrisma uzplaukumam. Attīstāmās teritorijas un objektiem ir jāievērtē aizsargzonas gar ievērojamiem Pāvilostas novada dabas objektiem - Baltijas jūras stāvkrasts, kas pēdējā laikā pakḷauts straujām erozijām, Pāvilostas "Pelēkā kāpa", dabas liegums "Ziemupe". 